\title{
Problematika Keterlambatan Bicara dan Gagap Pada Anak Usia 6 Tahun
}

\author{
Elisa Rahayu \\ PG-PAUD STKIP Modern Ngawi, elisarahayu6@gmail.com \\ Intan Widyaningsih \\ PG-PAUD STKIP Modern Ngawi, widyaningsihintan124@gmail.com \\ Bayu Adi Laksono \\ STKIP Modern Ngawi, bayuadi@ stkipmodernngawi.ac.id
}

\begin{abstract}
Abstrak
Keterlambatan Bicara (Speech Delay) dan Gagap yang dialami anak adalah dimana anak sulit mengekspresikan keinginan atau perasaan pada orang lain. Anak juga mengalami gagap, mengulang suara/suku kata terutama di awal, bicara gagap juga terdengar sebagai perpanjangan suara. Masalah keterlambatan bicara pada anak adalah masalah yang cukup serius yang harus segera ditangani karena keterlambatan bicara merupakan salah satu penyebab gangguan perkembangan yang paling sering ditemukan pada anak. Penelitian ini bertujuan untuk mengetahui ciri problematika dan masalah yang dihadapi serta faktor-faktor yang mempengaruhi keterlambatan bicara pada anak dan juga perlakuan yang diberikan oleh orang tua dan lingkungan dalam rangka menanggapi permasalahan ini. Penelitian ini tergolong jenis penelitian kualitatif dikarenakan untuk mendapatkan data maka peneliti harus turun kelapangan dan berada disana serta berbaur dengan subjek penelitian. Teknik pengumpulan data yang digunakan dalam penelitian ini ialah observasi, wawancara dan dokumentasi. Narasumber dalam penelitian ini yaitu pihak keluarga, masyarakat dan guru kelas. Hasil penelitian menunjukkan bahwa problematika anak sulit untuk berbicara lancar, anak mengalami gagap, lebih suka menyendiri, anak tidak banyak berbicara (pendiam). Keadaan Keluarga Anak, karena kedua orangtua sibuk bekerja dapat mengakibatkan pola asuh serta perkembangan anak terganggu terutama perkembangan bahasa anak. Keadaan Lingkungan anak, yaitu tempat tinggal juga mempengaruhi perkembangan bahasa anak.
\end{abstract}

Kata Kunci: Terlambat Bicara, Gagap, Problematik AUD

\section{PENDAHULUAN}

Anak dikategorikan masuk pada keadaan keterlambatan berbicara jika kemampuan bicaranya berada pada tingkat kemampuan bicara anak sebayanya (E. B. Hurlock, 1995). Lebih lanjut anak yang masuk dalam kategori terlambat bicara memiliki ciri yakni cenderung kurang tepat dalam menyebutkan kata pada usia dua tahun, kemudian memiliki jumlah penguasaan kata yang rendah di usia tiga tahun, dan juga mempunya kesulitan dalam memberikan nama pada benda di usia lima tahun (Papalia dkk., 2008). Hal tersebut merupakan ciri anak yang cenderung memiliki kesulitan dalam membaca.

Tingkat intelejesi ditengarai menjadi salah satu penyebab anak cenderung memiliki masalah dalam kemampuan berbicara. Hal tersebut tentunya sangat berbeda jika dibandingkan dengan anak-anak yang memiliki tingkat intelejensi yang tinggi. Hal lain yang diprediksi menjadi penghambat 
kemampuan berbicara anak adalah problema mengenai motivasi. Orang tua memiliki porsi penting dalam keadaan ini. Orang tua memiliki posisi yang strategis dengan memberikan kesempatan berkomunikasi secara intens kepada anak.

Faktor yang mempengaruhi kemampuan berbicara pada anak (E. B. Hurlock, 1995), yakni: faktor kecerdasan, kedisiplinan keluarga, urutan lahir anak, jumlah keluarga, status sosial dan ekonomi, suku, budaya bahasa, jenis kelamin. Semakin tinggi tingkat intelejensi anak tentu semakin tinggi pula kecakapan berbahasanya sehingga kemampuan dalam berbicara bisa dikuasai lebih cepat. Faktor selanjutnya yakni mengenai kedisiplinan dalam keluarga. Pola asuh yang diterapkan berbanding lurus dengan kecakapan anak dalam berbicara. Dalam keluarga yang menerapkan pola asuh dengan disiplin tinggi yang cenderung ke tingkat otoriter, tentu anak akan lebih sedikit mengungkapkan pikirannya secara langsung dalam bentuk bicara. Faktor selanjutnya yakni mengenai urutan anak dalam keluarga, anak sulung cenderug didorong untuk lebih banyak berbicara. Faktor lain yang mempengaruhi kemampuan anak dalam berbicara adalah jumlah dari anggota keluarga, dimana jumlah anggota keluarga berpeluang untuk memberikan interaksi komunikasi. Faktor sosial ekonomi mejadi faktor selanjutnya, keluarga ekonomi kelas bawah cenderung memiliki interaksi bicara yang rendah. Faktor selanjutnya yang berperan adalah latar belakang ras, dual-bahasa dalam keluarga, serta jenis kelamin.

Keterlambatan Bicara (Speech

Delay) dan Gagap yang dialami anak adalah dimana anak tersebut sulit mengekspresikan keinginan atau perasaan anak pada orang lain, seperti contoh anak tidak mampu berbicara dengan jelas. anak juga mengalami gagap seperti anak tersebut mengulang suara/ suku kata terutama di awal, terkadang bicara gagap juga terdengar sebagai perpanjangan suara. Terkadang juga berhenti bicara sepenuhnya dan mencoba mengulanginya. Kurangnya penguasaan kosa kata akan membuat anak tersebut berbeda dengan anak lain sesusianya, maka tak jarang anak dijauhi teman-temannya. Penanganan problem keterlambatan bicara pada anak harus ditangani secara serius karena merupakan problem perkembangan yang acapkali ditemukan pada anak.

Keterlambatan bicara merupakan kondisi dimana kemampuan bicara anak berada di bawah rata-rata kemampua bicara anak pada umumnya. Hal tersebut salah satunya dapat dilihat dari penggunaan kata yang tepat, dampaknya apabila kemampuannya di bawah rata-rata maka hubungan sosial anak akan terganggu (E. B. Hurlock, 1995). Apabila teman sebayanya berbicara menggunakan kata-kata, sedangkan si anak selalu menggunakan bahasa isyarat dan gaya bicara bayi, maka anak tersebut dianggap orang lain terlalu muda untuk diajak bermain.

Kemampuan berbicara anak dimulai dari keluarga, sekolah dan lingkungan masyarakat. Namun faktor utama dalam perkembangan bahasa anak adalah keluarga, apabila keluarga terlambat dalam menstimulus kecakapan anak dalam berbahasa dapat menghambat perkembangan berbicara anak karena dibandingkan dengan sekolah, waktu belajar anak lebih banyak dihabiskan dalam keluarga.

Lingkungan yang menunjang akan mengoptimalkan potensi genetik yang 
dipunyai seorang anak (Soetjiningsih, 1995). Faktor lingkungan secara garis besar dibagi menjadi faktor pranatal dan post natal. Lingkungan post natal secara umum dapat digolongkan menjadi lingkungan biologis (ras/suku bangsa, jenis kelamin, umur, gizi, perawatan kesehatan, kepekaan terhadap penyakit, penyakit kronis, fungsi metabolisme, hormon), fisik (cuaca, musim, keadaan geografis suatu daerah, sanitasi, keadaan rumah, radiasi), psikososial (stimulasi, motivasi belajar, ganjaran atau hukuman, kelompok sebaya, stres, sekolah, cinta dan kasih sayang, kualitas interaksi anak-orangtua) dan keluarga beserta adat istiadat (pekerjaan, pendapatan keluarga, pendidikan ayah/ibu, jumlah saudara, jenis kelamin dalam keluarga, stabilitas rumah tangga, kepribadian ayah/ibu, adat istiadat, agama, urbanisasi, politik) (Soetjiningsih, 1995). Intervensi perkembangan anak tidak hanya tentang makanan, tetapi juga pola asuh dan kualitas interaksi ibu-anak, dan yang paling besar adalah status sosial-ekonomi (Engle \& Huffman, 2010)

Sebagai pendidik anak usia dini tidak jarang kita menjumpai anak dengan kesulitan bicara (speech delay) dan gagap. Dalam menghadapi situasi dan kondisi tersebut pendidik wajib memiliki sebuah rasa peka sehingga saat menjumpai anak dengan kondisi tersebut kita dapat mengambil langkah atau cara-cara yang tepat untuk menanganinya. Kita sebagai pendidik juga harus memiliki komunikasi dengan orangtua anak agar setiap kondisi anak dalam pembelajaran dapat dipahami dengan baik. Orangtua juga akan memahami kondisi anak serta mendapatkan solusi dan penanganan yang tepat. Anak yang mendapat simulasi yang terarah dan teratur akan lebih cepat berkembang dibandingkan dengan anak yang kurang/tidak mendapat stimulasi (Soetjiningsih, 1995).

Alasan penelitian adalah supaya mengetahui penyebab dari problematika yang sedang dialami oleh anak, supaya mengetahui lingkungan dan faktor- faktor yang menyebabkan anak mengalami masalah tersebut serta supaya mengetahui cara yang sudah ditempuh dari pihak terdekat anak untuk mengatasi kondisi si anak kemudian agar peneliti mengetahui dan memahami perlakuan-perlakuan yang dapat dilakukan untuk menanggapi dari permasalahan tersebut serta dapat mndeteksi sedini mungkin kondisi atau masalah yang sedang dialami oleh si anak.

Tujuan penelitian ini adalah untuk mengetahui ciri problematika dan masalah yang sedang dialami anak yaitu kesulitan bicara (speech delay) dan gagap, faktorfaktor dari keluarga maupun lingkungan yang ikut mempengaruhi perkembangan bahasa anak tersebut, serta mendeteksi sejak dini keterlambatan berbicara pada anak, karena jika dimulai sejak dini maka semakin baik kemungkinan pemulihan hambatan tersebut dan stimulus-stimulus yang sesuai untuk anak tersebut.

Kegunaan Penelitian ini diharapkan dapat memahami lebih dalam bagaimana perkembangan bicara pada anak terutama mengenai keterlambatan bicara (speech delay) dan gagap. Dapat memperoleh informasi tentang faktor-faktor yang dapat mempengaruhi dari keterlambatan bicara (speech delay) dan juga perlakuanperlakuan yang dapat dilakukan untuk menanggapi dari permasalahan tersebut. Bagi orang tua penelitian ini berguna untuk lebih memperhatikan berbagai macam faktor yang dapat menghambat perkembangan anak. Terutama faktorfaktor yang berhubungan dengan keterlambatan bicara (speech delay) dan 
gagap pada anak sehingga dapat diminimalisir agar anak dapat tumbuh dan kembang secara wajar. Bagi masyarakat, Masyarakat diharapkan ikut ambil alih dalam menanggapi permasalahan keterlambatan bicara (speech delay) dan gagap pada anak serta diharapkan dapat mengurangi dampak yang akan terjadi di masa yang akan datang.

\section{METODE}

Penelitian ini tergolong jenis penelitian kualitatif dikarenakan untuk mendapatkan data, peneliti turun kelapangan dan berada disana serta berbaur dengan subjek penelitian. Penelitian ini memberikan data berupa gambaran terhadap hasil penelitian lapangan pada anak yang mengalami kondisi keterlambatan bicara (speech delay) dan gagap. Teknik pengumpulan data yang digunakan dalam penelitian ini ialah observasi, wawancara dan dokumentasi. Analisis data menggunakan model Analysis Interactive yang membagi kegiatan analisis menjadi beberapa bagian yaitu: pengumpulan data, reduksi data, penyajian data, dan penarikan kesimpulan atau verifikasi data (Miles \& Huberman, 1994). Secara umum analisis data dalam penelitian ini dilakukan melalui tahapantahapan sebagai berikut; (1) mencatat semua temuan fenomena di lapangan baik melalui pengamatan, wawancara dan dokumentasi; (2) menelaah kembali catatan hasil pengamatan, wawancara dan studi dokumentasi, serta memisahkan data yang dianggap penting dan tidak penting, pekerjaan ini diulang kembali untuk memeriksa kemungkinan kekeliruan klasifikasi; (3) mendeskripsikan data yang telah diklasifikasikan dengan memperhatikan fokus dan tujuan penelitian; dan (4) membuat analisis akhir dalam bentuk laporan hasil penelitian.
Sumber penelitian ini adalah subjek penelitian yaitu anak dengan keterlambatan bicara (speech delay) dan gagap serta narasumber. Subjek penelitian ini adalah anak yang berusia 6 tahun dengan masalah pada gangguan berbicara yaitu keterlambatan bicara (speech delay) dan gagap, yang bersekolah di TK Dharma Wanita Dinden. Narasumber dalam penelitian ini yaitu pihak keluarga, masyarakat dan guru kelas. Tempat dan waktu Penelitian dilakukan di TK Dharma Wanita Dinden Desa Dinden Kecamatan Kwadungan Kabupaten Ngawi. Alasan memilih TK Dharma Wanita Dinden karena terdapat anak yang mengalami problematika keterlambatan bicara (speech delay) dan gagap. Kegiatan dilakukan oleh peneliti pada Oktober 2019.

\section{HASIL DAN PEMBAHASAN}

Hasil

A. Problematika

Berdasarkan wawancara dengan guru kelas mengenai anak yang berusia 6 tahun tetapi sulit untuk berbicara lancar, ketika berbicara anak tersebut mengulang suara/ suku kata terutama di awal, seperti "da-da-dalem" karena awal pembelajaran selalu diabsen gurunya, terkadang bicara gagap juga terdengar sebagai perpanjangan suara seperti "sssssssuka". Terkadang juga berhenti bicara sepenuhnya dan mencoba mengulanginya, ketika istrirahat anak lebih suka menyendiri dan tidak banyak berbicara (pendiam). Dalam proses di luar pembelajaran guru pernah secara personal mencoba membangun interaksi kepada anak. Meskipun respon anak secara umum minim, namun anak sebenarnya memiliki keinginan besar untuk memberikan respon. Hal tersebut dapat dilihat dari semangatnya dalam merespon pertanyaan dari guru. Problematika lain dalam kasus 
keterlambatan bicara adalah tindak perundungan/bullying. Guru memaparkan dalam proses pembelajaran baik di luar maupun di dalam kelas anak yang memiliki keterlambatan berbicara cenderung mendapat tekanan dari siswa lain, terutama dalam bentuk perundungan secara verbal. Beberapa bentuk konseling yang dilakukan oleh guru yakni mengajak anak berbicara dengan cara bercerita, memperbaiki pengucapan kata anak yang keliru, memperhatikan anak dengan sabar tidak memaksa harus lancar berbiacara, ketika les membaca guru memberikan waktu lebih dengan membaca keras, karena dengan keras dapat mngajarkan anak bernapas dengan baik, melibatkan anak dalam percakapan ketika di luar pembelajaran, biarkan anak bercerita dan mengekspresikan ide-ide sendiri.

Selain guru, problematika keterlambatan bicara erat kaitannya dengan keadaan keluarga anak. Berdasarka hasil wawancara kepada keluarga menyatakan bahwa orangtua belum melakukan hal apapun kepada anak termasuk diperiksa oleh pihak medis. Pihak keluarga percaya bahwa gagap dapat hilang dengan sendirinya, untuk kesulitan bicara anak kurang dilatih saja. Maka selama ini yang dilakukan pihak keluarga adalah sekedar mengajarkan mambaca, bernyanyi dengan keras, menemani mengerjakan prakarya, bernyanyi tetapi kadang anak tidak menyukai benyanyi. Anak lebih menyukai mainan sendiri dan memilih diam. Melengkapi keterangan dari pihak keluarga, pihak masyarakat sekitar yang memahami problematika anak dengan keterlambatan bicara mengungkapkan bahwa interaksi anak cenderung sangat kurang dengan teman sebaya serta orang tua. Hal tersebut terungkap bahwa anak hanya memberikan respon anggukan sebagai tanda persetujuan serta gelengan sebagai tanda ketidaksetujuan pada komunikasi yang dibangun oleh pihak lain.

\section{B. Kondisi Lingkungan}

Keluarga dari anak dengan keterlambatan bicara cenderung berasal dari keluarga menengah dan ke bawah dengan ritme kerja orang tua yang sibuk yang dampaknya adalah interkasi yang rendah antara orang tua dengan anak. lingkungan sekolah berada satu atap dengan sekolah dasar yang terkadang menjadikan pembelajaran tidak kondusif karena anak sekolah dasar bermain di depan kelas. Pengelolaan lingkungan serta sarana-prasarana termasuk alat permainan edukatif (APE) tersedia di dalam dan di luar kelas, tetapi untuk alat permainan edukatif (APE) yang khusus untuk merangsang bahasa anak kurang memadai.

\section{Pembahasan}

\section{A. Problematika}

Berdasarkan hasil penelitian yang didapatkan di lapangan umumnya pada subjek penelitian menunjukkan adanya ciri-ciri gangguan anak dalam berbicara seperti: tidak banyak berbicara (cenderung pendiam), belum mampu berbicara dengan lancar, kurangnya penguasaan kosa kata, pengucapan kata yang masih keliru, pengungkapan kalimat yang tidak jelas. Hal ini sesuai dengan pernyataan informan "pada umumnya anak usia 2 tahun sudah mampu berbicara jelas, tepat dan lugas begitu juga sebaliknya jika pada usia tersebut anak belum mendapatkannya maka anak tersebut mengalami keterlambatan dalam berbicara katagori ringan". Berdasarkan wawancara dengan guru, anak tersebut sulit untuk berbicara lancar, dan ketika berbicara, anak tersebut 
mengulang suara/ suku kata terutama di awal, terkadang bicara gagap juga terdengar sebagai perpanjangan dan berhenti bicara sepenuhnya serta mencoba mengulanginya. Berdasarkan wawancara dengan keluarga, orangtua belum membawa anaknya ke dokter, karena percaya bahwa dengan mengabaikan kondisi tersebut dipercaya dapat membuat gagap hilang dengan sendirinya, untuk kesulitan bicara anak kurang dilatih saja. Padahal strategi/teknik sederhana dapat dilakukan orangtua dalam mengatasi anak yang terlambat berbicara dan segera di bawa ke pihak medis. Melatih anak berbicara dengan benar, pelan dan berulang-ulang. Hal ini sesuai dengan pernyataan (Santrock, 2009) mengatakan bahwa di dalam atau di luar sekolah, dukungan terhadap perkembangan bahasa bahkan latihan dan ulangan merupakan kuncinya. Saat berbicara selalu memperhatikan tata bahasa yang diucapkan. Hal ini sesuai dengan teori Roger Brown (Santrock, 2009) mengatakan bahwa orangtua mendorong anak-anak mereka untuk berbicara dengan tata bahasa yang benar. Berdasarkan wawancara lingkungan sekitar, anak lebih suka bermain sendiri dirumah, terkadang anak juga ikut bermain dengan temantemannya, ketika bermain dengan teman temannya tergolong anak yang pendiam, tidak seperti teman-teman yang lainnya. Apabila teman mengajaknya bermain terkadang anak hanya melihat, dan anak lebih asyik bermain sendiri. Beberapa ciri orang yang introvert, yaitu terutama dalam keadaan emosional dan konflik, orang dengan kepribadian ini cenderung menarik diri dan menyendiri (Eysenck \& Wilson, 1976).

\section{B. Keadaan Keluarga}

Keadaan keluarga anak, karena kedua orangtua sibuk bekerja dapat mengakibatkan pola asuh serta perkembangan anak terganggu terutama perkembangan bahasa anak, hal ini dudukung oleh teori para ahli bahwa Interaksi yang dilakukan orang tua terhadap anak sangat memegang peranan penting dalam perkembangan anak, apabila interaksi dan stimulasi yang diberikan orang tua baik maka perkembangan anak pun akan optimal (Aisyah dkk., 2014). Keluarga terutama ayah dan ibu merupakan lingkungan sosial pertama dan utama bagi anak sehingga memberi pengaruh besar bagi perkembangan anak. Pengalaman interaksi dalam keluarga akan menentukan pola dan tingkah anak di lingkungannya (Soetjiningsih, 1995). Perkembangan awal anak memerlukan pola asuh yang responsif (Black dkk., 2016).

Usaha-usaha yang seharusnya orangt ua lakukan dalam mengembangkan kecakapan berbicara anak terdiri atas: mengajak berbicara, bertanya disetiap kesempatan, mengarahkan, memperbaiki kalimat yang salah, berbicara dengan pelan serta selalu menggunakan bahasa yang jelas saat berbicara, konsultasi dengan dokter spesialis anak dan psikolog anak mengekspresikan perasaan mereka. Bahasa ekspresif (Expresive Languange) melibatkan kemampuan untuk menggunakan bahasa dalam mengungkapkan pemikiran seseorang dan berkomunikasi dengan orang lain, beberapa anak dapat dengan mudah memahami apa yang dikatakan mereka, tetapi mereka mempunyai kesulitan ketika mereka berusaha untuk merespon dan mengungkapkan diri mereka sendiri (Santrock, 2009). Orangtua seharusnya memiliki kualitas waktu serta kemampuan 
dalam mendeteksi tumbuh kembang anak khususnya perkembangan bahasa anak. Ayah juga memiliki peran yang sangat strategis dalam pendampingan tumbuhkembang anak, terutama dalam perkembangan emosi anak (Wijayanti, 2018). Selain itu pendampingan orang tua berguna untuk meningkatkan efikasi diri anak, dimana efikasi diri seseorang dapat meningkatkan kemampuan berbahasanya (Laksono, 2018)

\section{Keadaan Lingkungan}

Keadaan lingkungan anak, keadaan lingkungan tempat tinggal juga mempengaruhi perkembangan bahasa anak, dimana lingkungan dipedesaan dengan kondisi kekeluargaan yang masih erat dan sosialisasi dengan lingkungan masih baik, maka kontak anak dengan anak yang sebaya masih cukup intensif. Kontak anak dengan anak sebaya inilah yang mendorong perkembangan bahasa anak (Soetjiningsih, 1995). Jenis kelamin menunjukan bahwa pada perempuan, pengaktifan otak berlangsung pada kedua hemisfer dan pada area yang lebih luas. Perempuan mampu mengingat sejumlah gambaran emosi yang jauh lebih tinggi dibandingkan laki-laki dan secara emesional perempuan jauh lebih efektif dibandingkan dengan laki-laki dalam dalam pemerolehan bahasa secara alamiah (Arrifudin, 2010). Selain itu, faktor lingkungan biologis mempengaruhi tumbuh kembang bahwa anak laki-laki lebih sering mengalami gangguan dari pada anak perempuan, namun hal ini belum diketahui penyebabnya secara pasti, namun hasil dari penelitian didapatkan jumlah keterlambatan pada anak laki-laki dan anak perempuan seimbang (Soetjiningsih, 1995). Anak yang menjalin hubungan dengan keluarganya secara sehat (penuh perhatian dan kasih sayang dengan orangtuanya) dapat memfasilitasi perkembangan bahasa anak. Sebaliknya jika hubungan anak dan orangtuanya tidak sehat, maka perkembangan bahasa anak cenderung mengalami kelainan seperti gagap, katakatanya tidak jelas, berkata kasar dan tidak sopan serta merasa takut untuk mengungkapkan pendapatnya (Adriana, 2008).

Faktor usia orang tua dapat mempengaruhi pola asuh orangtua. Umur merupakan salah satu ciri tingkat kedewasaan dimana dapat mempengaruhi perannya terhadap anak karena dengan bertambahnya umur seseorang maka terjadi proses kematangan baik organ maupun jalan fikirannya sehingga dapat memberikan pola asuh yang tepat pada anaknya. Usia orang tua merupakan salah satu faktor yang mempengaruhi kesiapan orang tua dalam menjalankan peran pengasuhan terhadap anaknya. Usia yang terlalu muda atau yang terlalu tua dapat mengakibatkan orang tua tidak dapat melaksanakan peran pengasuhan secara optimal (Syam, 2013). Untuk Pendidikan orangtua dapat mempengaruhi penerapan pola asuh orangtua terhadap anak. Pendidikan orangtua Dengan pendidikan orangtua akan memberikan dampak bagi pola pikir dan pandangan orangtua terhadap cara mengasuh dan mendidik anaknya. Sehubungan dengan tingkat pendidikan orangtua akan memberikan pengaruh terhadap pola berfikir dan orientasi pendidikan yang diberikan kepada anaknya. Semakin tinggi pendidikan yang dimiliki oleh orangtua maka akan semakin memperluas dan melengkapi pola berfikirnya dalam mendidik anaknya (Soetjiningsih, 1995). Lingkungan tempat tinggal yang ideal yakni kondisi kekeluargaan yang masih 
erat dan sosialisasi yang baik karena mempengaruhi perkembangan bahasa anak. Ketika orang-orang disekitar anak mengajak bicara atau berkomunikasi dengan suara yang jelas dan kalimat yang masih sederhana, maka akan memudahkan anak dalam mempelajari kalimat atau kata yang telah didengarkan dari orang tersebut. Tidak mengejek anak dengan sebutan anak gagap, karena dapat membuat anak merasa tidak semangat untuk belajar berbicara dengan baik. Keadaan lingkungan sekolah juga mempengaruhi perkembangan bahasa anak, dimana lingkungan yang kondusif serta fasilitas-fasilitas yang disediakan guru dapat mendorong perkembangan bahasa anak. Guru bertugas untuk membimbing, mengarahkan, merangsang kemampuan, potensi serta minat dan bakat yang ada dalam diri anak. Guru dalam membantu perkembangan anak mewujudkan tujuan hidupnya secara optimal baik dalam membimbing, mengajarkan maupun mengarahkan, minat, bakat, kemampuan dan potensi-potensi yang dimiliki oleh anak tidak akan berkembang secara optimal tanpa peran guru (Mulyasa, 2004).

Usaha-usaha yang dapat dilakukan guru dalam mengatasi anak yang terlambat berbicara (speech delay) dan gagap yaitu penanganan yang dilakukan oleh guru didalam pembelajaran dalam mengatasi dan mengembangkan kecakapan anak dalam berbicara, terdiri atas: berbicara dengan jelas dengan menunjukkan gerak mulut serta artikulasi yang tepat, dan memperhatikan tata bahasa yang diucapkan. Sedangkan usaha dan metode yang digunakan guru ialah terdiri atas: mengajak anak berbicara dengan cara bercerita, memperbaiki pengucapan kata anak yang keliru, memberi kesempatan untuk anak berbicara, dan menggunakan metode tanya-jawab dengan anak, untuk melihat sejauh mana perkembangan bahasa yang ditunjukkan oleh anak. Guru seharusnya memiliki strategi atau kemampuan dalam mengembangkan kecakapan berbahasa anak di sekolah. Fasilitas sekolah, pengelolaan lingkungan serta sarana-prasarana termasuk alat permainan edukatif (APE), guru sebaiknya menyediakan alat permainan edukatif (APE) yang memadai sehingga memudahkan guru dalam merangsang aspek-aspek perkembangan anak khususnya aspek bahasa anak.

\section{PENUTUP}

\section{Simpulan}

Anak yang mengalami keterlambatan dalam berbicara usia 6 tahun menunjukkan ciri-ciri sulit mengekspresikan keinginan atau perasaan anak pada orang lain, seperti contoh anak tidak mampu berbicara dengan jelas. anak juga mengalami gagap seperti anak tersebut mengulang suara/ suku kata terutama di awal, terkadang bicara gagap juga terdengar sebagai perpanjangan suara. Terkadang juga berhenti bicara sepenuhnya dan mencoba mengulanginya. Kurangnya penguasaan kosa kata akan membuat anak tersebut berbeda dengan anak lain sesusianya, maka tak jarang anak dijauhi temantemannya. Peran serta orangtua, lingkungan dan orang sekitar sangat menentukan kemampuan berbicara anak. Serta memberikan pemahaman kepada orangtua, guru, serta lingkungan bahwa tidak selamanya anak yang mengalami keterlambatan berbicara tidak bisa bersoisalisasi dengan lingkungan di sekitarnya

\section{SARAN}


Saran kepada pihak orangtua sebaiknya ajak anak untuk berkomunikasi di rumah, mengajak anak untuk bersosialisasi dengan orang-orang di lingkungannya, tidak meniru bahasa anak saat anak berbiacara gagap, jika mengetahui sedini mungkin masalah anak, segera dikonsultasikan dengan pihak medis. Saran kepada guru yakni memperbaiki pengucapan kata anak yang keliru, memperhatikan anak dengan sabar tidak mengucilkan anak, selalu mendampingi anak, dan memberikan anak kesempatan untuk mengekspresikan ideidenya jangan terlalu dipaksa.

\section{DAFTAR PUSTAKA}

Adriana, I. (2008). Memahami pola perkembangan bahasa anak dalam konteks pendidikan. TADRIS: Jurnal Pendidikan Islam, 3(1).

Aisyah, S., Amini, M., Chandrawati, T., \& Novita, D. (2014). Perkembangan dan konsep dasar pengembangan anak usia dini.

Arrifudin. (2010). Neuropsikolinguistik. Raja Grafindo Persada.

Black, M. M., Fernandez-Rao, S., Hurley, K. M., Tilton, N., Balakrishna, N., Harding, K. B., Reinhart, G., Radhakrishna, K. V., \& Nair, K. M. (2016). Growth and development among infants and preschoolers in rural India: Economic inequities and caregiver protective/promotive factors. International Journal of Behavioral Development, 40(6), 526-535.

E. B. Hurlock. (1995). Perkembangan Anak (I). Erlangga.

Engle, P., \& Huffman, S. L. (2010). Growing children's bodies and minds: Maximizing child nutrition and development. Food and nutrition bulletin, 31(2_suppl2), S186-S197.

Eysenck, H., \& Wilson, G. (1976). Know your own personality. Pelicon.
Laksono, B. A. (2018). The Effect Of SelfEfficacy On English Training Results. EMPOWERMENT: Jurnal Ilmiah Program Studi Pendidikan Luar Sekolah, 7(2), 39-46.

Miles, M. B., \& Huberman, A. M. (1994). Qualitative data analysis: An expanded sourcebook (2 ed.). sage.

Mulyasa, E. (2004). Implementasi Kurikulum 2004 panduan pembelajaran $K B K$. Remaja Rosdakarya.

Papalia, D. E., Old, S. W., \& Feldman, R. D. (2008). Human Development (Psikologi Perkembangan). Prenada Media Group.

Santrock, J. W. (2009). Psikologi Pendidikan Edisi 3 Buku 2. Salemba Humanika.

Soetjiningsih. (1995). Tumbuh kembang anak (Vol. 1). EGC.

Syam, S. (2013). Hubungan Pola Asuh Orang Terhadap Kejadian Temper Tantrum Anak Usia Toddler Di Paud Dewi Kunti Surabaya. 1(2), 164-169.

Wijayanti, A. (2018). Peran Pengasuhan Ayah Terhadap Perkembangan Emosi Anak. Seminar Nasional dan Call for Paper "Membangun Sinergitas Keluarga dan Sekolah Menuju PAUD Berkualitas, 23-26. 